\title{
Prevalence of risk factors for foot ulceration in a general haemodialysis population
}

\author{
Nia Jones*, Stephen Riley, Aled Phillips \\ From Society of Chiropodists and Podiatrists Annual Conference 2010 \\ Bournemouth, UK. 21-23 October 2010
}

\section{Background and objectives}

Lower limb complications contribute to the significantly increased morbidity and mortality associated with renal replacement therapy. This audit was designed to document the prevalence of known risk factors for foot ulceration in a stable haemodialysis population.

\section{Design, setting, participants and measurements}

A dedicated podiatric service was introduced into a satellite haemodialysis unit. All patients were invited to have a session with the podiatrist to have a formal assessment of their feet. The Renal Foot Screening Tool was developed to prospectively identify risk factors associated with foot ulceration present in individual patients. This included identification of peripheral neuropathy, peripheral arterial disease, and structural foot pathology. In addition basic demographic and co-morbidity data was collected.

\section{Results}

Of 57 patients screened 24 had diabetes mellitus. Peripheral neuropathy was identified in $50 \%$ and $18 \%$ of diabetic and non-diabetic patients respectively. Peripheral arterial disease as documented by Doppler studies was documented in $45 \%$ of diabetic and $30 \%$ of nondiabetic patients. A high percentage (79\%) of patients had some form of structural foot pathology. Forty nine percent of the total cohort had 2 or more risk factors for foot ulceration (16/24 diabetic v 12/33 non-diabetic).

\section{Conclusions}

There is a high prevalence of risk factors for foot ulceration in this group of haemodialysis patients. This suggests these patients are at high risk of future foot ulceration, which may lead to amputation. Further work

Cardiff and Vale University Health Board, Cardiff, UK on strategies to monitor and prevent foot pathology may lead to a reduction in morbidity and mortality associated with foot ulceration.

Published: 20 December 2010

doi:10.1186/1757-1146-3-S1-013

Cite this article as: Jones et al:: Prevalence of risk factors for foot ulceration in a general haemodialysis population. Journal of Foot and Ankle Research 2010 3(Suppl 1):013.
Submit your next manuscript to BioMed Central and take full advantage of:

- Convenient online submission

- Thorough peer review

- No space constraints or color figure charges

- Immediate publication on acceptance

- Inclusion in PubMed, CAS, Scopus and Google Scholar

- Research which is freely available for redistribution
() Biomed Central

\section{Biomed Central}

(c) 2010 Jones et al; licensee BioMed Central Ltd. This is an open access article distributed under the terms of the Creative Commons Attribution License (http://creativecommons.org/licenses/by/2.0), which permits unrestricted use, distribution, and reproduction in any medium, provided the original work is properly cited. 